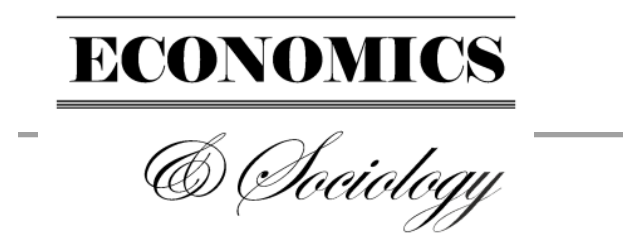

Musová, Z., Musa, H., \& Ludhova, L. (2018). Environmentally responsible purchasing in Slovakia. Economics and Sociology, 11(4), 289-305. doi:10.14254/2071789X.2018/11-4/19

\title{
ENVIRONMENTALLY RESPONSIBLE PURCHASING IN SLOVAKIA
}

\author{
Zdenka Musova, \\ Matej Bel University in Banská \\ Bystrica, Faculty of Economics, \\ Banská Bystrica, Slovakia, \\ E-mail:_denka.musova@umb.sk \\ Hussam Musa, \\ Matej Bel University in Banská \\ Bystrica, Faculty of Economics, \\ Banská Bystrica, Slovakia, \\ E-mail:bussam.musa@umb.sk. \\ Lenka Ludhova, \\ Matej Bel University in Banská \\ Bystrica, Faculty of Economics, \\ Banská Bystrica, Slovakia, \\ E-mail:lenka.ludhova@gmail.com
}

Received: May, 2018

1st Revision: June, 2018

Accepted: November, 2018

DOI: $10.14254 / 2071-$

789X.2017/11-4/19

\begin{abstract}
The current state of the environment encourages consumers to more responsible behaviour in the market. Consumers realize that through their purchase behaviour they can also contribute to the reduction of negative developments and betterment of the situation. In that context, our aim was to examine the selected aspects of environmental purchase behaviour of consumers in Slovakia. Our attention was focused on the environmental factors when purchasing products in general. The partial aim was to find out how consumers behave when purchasing environmental products with an emphasis on bio products and organic food. Secondary data analysis is supplemented by the selected results of the primary research from February 2017, which was conducted on the sample of 274 respondents from Slovakia. The obtained data were evaluated by selected statistical methods (Chisquare test, Friedman test, Wilcoxon test, descriptive statistics). The results of the research showed that environmental factors when purchasing products do not dominate among Slovak consumers. The frequency of purchasing selected environmentally friendly products (including bio products and organic food) does not seem important. Our research identified several drawbacks in environmental behaviour of consumers and mentioned the need for more environmental education among consumers and more intensive communication of environmentally responsible businesses in relation to their potential environmental-oriented customers.
\end{abstract}

Keywords: consumer behaviour, purchase, environmentally responsible consumer, environmentally friendly product, bio product, organic food, Slovakia.

\section{Introduction}

Negative course of events in the environment is an important factor, which in the present influences the behaviour of all market subjects. Environmental problems are deepening and, in many cases, become global. The necessity to solve them is a challenge for businesses and consumers too. Many consumers act responsibly towards the environment, their environmental awareness grows, and they emphasise their environmental requirements while performing purchases. They contemplate which products to buy and from which seller. They are willing to pay more and accept a lower level of convenience when buying 
environmental products, for example, a shorter period of shelf life or the usage of refundable packaging. They take into account what materials are the products made of, what amount of energy is used in the production process, what fallouts did the production have on the surrounding environment, the way the product was distributed and the possibilities of removing the product after its end of use.

These considerations and increased demands of consumers in the context of environmental product characteristics are at the same time a challenge for businesses, to act more responsibly and improve their business activities through the addition of an environmental dimension. Environmentally oriented behaviour of businesses in these times of global dynamic changes is one of the factors of long-term economic success and a tool to improve their competitive position (Kljucnikov et al., 2016). At the same time, businesses have to put a larger emphasis on the research of the abovementioned characteristics of consumers and their behaviour.

In today's highly informed, competitive and saturated market, a key to success of any business depends on knowing consumer, recognizing the factors influencing their decisionmaking and understanding their way of thinking and pattern of conduct for the purpose of developing an attractive offer of products, supporting services, communication means and other marketing tools in relation to customer needs and expectations (Kurajdova et al., 2015). The study of consumer behaviour and customer satisfactions belongs to a group of very important and significant, long-term subjects of marketing's attention and their examination requires ongoing approach.

In the outlined context, our paper focuses on the research of the selected aspects of consumer behaviour and their decision-making processes with respect to the purchase of environmental products. Firstly, our attention is directed to the factors influencing consumer behaviour in general. Considering the research object, next we opt for the factors influencing responsible consumer behaviour, especially environmental factors (e. g., environmental friendliness of products, ecological production, eco-labelling of products). In detail, we examine buying of selected "environmentally friendly products" (which products, how often). The partial aim is to investigate how consumers behave when purchasing bio products and organic food.

Various consumer segments can be found at the market based on the approach towards the environment and environmental behaviour. A distinct environmental sentience is typical for some segments and they display an enthusiastic interest in everything related to environmental protection. On the other hand, we also register segments, the members of which are completely indifferent to environmental questions. A careful study and examination of responsible consumer behaviour, environmental factors taking consumers into account when purchasing and preferring environmental products could enable companies not only understand better what is important to a customer when making decision about a product purchasebut also why they behave in the way they behave. This knowledge may help them predict customers' behaviour and consequently influence them by applying various marketing tools with the intention to reach their satisfaction and, in the best case, their loyalty. With regard to these different characteristics of target segments and subsequently their different reactions to marketing stimuli, our findings can be relevant for business practice, planning and implementation of appropriate environmental marketing strategies.

The authors have chosen the following logical structure of the paper. In the Introduction intentions and goals of the authors are briefly outlined. Section 1 presents the relevant literature review and secondary data analysis (previous research). Section 2 explains the suggested research methodology. Section 3 is dedicated to the primary research and its 
selected results focused on the environmentally responsible consumer behaviour. The Conclusion sums up the most important findings and recommendations for future research.

\section{Literature review}

The study of consumer behaviour and customer satisfaction belongs to a group of very important and significant subjects of marketing's attention and their examination requires continual and ongoing approach. Consumer behaviour is understood as behaviour that consumers display in searching for, purchasing, using, evaluating and disposing of products and services that they expect will satisfy their needs (Schiffman \& Kanuk, 2004).

Consumer behaviour is determined by the amount of factors. The origin of some is in the environment, a part of which is the consumer (external effects), others relate to his individual characteristics (internal factors), and the purchasing situation itself has an effect as well (situational factors). Besides that, businesses try to influence consumers through a whole range of marketing stimuli.

In marketing theory, there exists a whole range of models dealing with the issue of consumer behaviour. Kotler's model of reaction to stimuli (so called black box model) could be designated as the most frequent model of consumer behaviour in marketing literature. The consumer is presented as a black box, with various marketing (elements of marketing mix) and other (economic, technological, political, cultural) inputs/stimuli. The outputs from it are various buyer responses in the form of selection of product, brand, seller, quantity, purchase time. The final decision is influenced by various characteristics of the consumer, as well as the process of purchase decision-making itself. Through the correct understanding of the black box model, and factors, which influence purchase behaviour of the consumer, even marketers gain a better chance of predicting, how the consumer will react to their marketing strategy (Kotler \& Armstrong, 2004).

A significant model of consumer behaviour is the model of environmentally conscious behaviour (The environmental value-attitude-system model by Dembkowski and HammerLloyd). Environmental awareness of consumers is one of the influential factors of purchasing behaviour and it comprises a part of value-attitude system of the consumer. A cognitive part contains thoughts, opinions and knowledge of the consumer about the environment. It states that individual consumers have subjective knowledge about environmental consequences of their activities. The emotions and feelings of the consumer towards the environment comprise an affective part of environmental awareness. Creative part focuses on the tendencies of consumer behaviour with regards to the environment. Environmentally oriented behaviour assumes that the consumer tends to behave in a way that contributes to environmentally beneficial solutions. Environmental awareness has to be understood as a part of a broad system of values and attitudes of man (Richterova et al., 2015).

Consumer behaviour substantially influences even global trends. Current concerns also include increased consumers' interest in greater responsibility and ethical, environmental, and social approach in business. Recent consumer is more informed, more educated, more demanding on the brand and quality of the product and is increasingly interested in how the product is produced, whether it respects employees' rights, environmental pollution standards, what reputation the manufacturer/retailer has. With more responsible behaviour especially towards oneself, as well as towards their surroundings, the consumer becomes the driver of social responsibility and can create substantial pressure on businesses and their responsible behaviour. Businesses encounter the "responsible consumer" increasingly more, who can be defined as a person informed and awared of its consumer habits. He knows and procures his 
consumer rights, selects his products with the least possible negative influence on the environment and considers their influence on the society as a whole.

Numerous studies (Gilg et al., 2005; Mainieri, T. et al., 2010; Marques \& Almeida, 2013; Pedrini \& Ferri, 2014; Barbarossa \& Pastore, 2015; Raletic Jotanovic et al., 2016; Shamsi \& Siddiqui, 2017) have been conducted with the aim of examining specifics of environmentally-conscious/responsible behaviour of consumers. The consumers belonging to the environmental market segment are those who are characterized by their self-fulfilment. These people always believe in self-improvement and take action, which are challenging. They are interested in ecological lifestyle, i.e. environmental consciousness, selecting and rejecting products and also volunteering themselves in various events, which are introduced to protect the environment. This segment would naturally welcome changes and take interest in those firms which are committed to environment and launch new products and showing them as a new exciting experiences (Fraj \& Martinez, 2007). Paul and Rana (2012) complete, that the consumers in this segment during shopping are interested in environmental products, not merely because of healthier option but in also hope in sustaining the environment for future generation. According to the study by Mostafa (2007) most environmental consumers are well-educated, young adult women, who have more money to spend. They expect green products to satisfy their needs. Environmental benefits are additional attraction for them. Moreover, they are conscious about the environmental claims. They are ready to pay premium price after verifying the environmental claims and individual benefits given to them. Bui (2005) confirmed, green consumer generally falls in the following category: educated, premiddle aged females earning mid to high-incomes. Although much research has been done on the demographic profiles of "green consumers" findings are still relatively mixed with some demographic characteristics showing more consistent results than other. Most studies appear to indicate a limited or ambiguous value of socio-demographic characteristics for segmenting and targeting environmentally conscious consumers (Diamantopoulos et al., 2003).

Being aware of the destruction of natural resources as a result of human activities and the need for the preservation of the environment have increased environmental awareness of consumers (Kumar, \& Ghodeswar, 2015). Growing environmental problems caused by industrialization have increased the environmental concerns of customers, communities and governments (Chiou et al., 2011). An increasing number of consumers tend to purchase and consume products that are presented in an environment-friendly way (Esmaeilpour \& Bahmiary, 2017). Changes in consumer behaviour have helped the beginning of green revolution meant to avoid further harm to the environment (Juwaheer et al., 2012). Thus, the issue of preserving our environment has caused consumers to rethink their choice of products and for the protection of the environment, many consumers are ready to pay higher prices for products that comply with environmental standards (Newton et al., 2015). The impact of this is seen when companies are turning more towards environmentally friendly products (Finisterra et al., 2009).

Environmentally responsible consumer (the green consumer, ecologically conscious consumer) can be defines as a consumer that takes into account the public consequences of his or her private consumption or who tries to use his or her purchasing power to promote social change (Webster, 1975). Furthermore, these consumers' behaviour reflects their attitudes and actions toward environmental protection (Fraj \& Martinez, 2006). The term "environmental product" (or "green product") usually describe products that protect or enhance the natural environment, the conservation of energy, and the reduction or elimination of toxic agents, pollution, and waste (Ottman et al., 2006). From the environmental point of view, a product can be understood as a critical marketing tool. Although a product is the cause of pollution, it can also be the tool reducing the negative impact on the environment. Decision 
about the product can help fulfil the environmentally-oriented demands of customers. Most authors (Stead, \& Stead, 1996; Kusa, 2012; Krizanova, Majerova, \& Zvarikova, 2013; Zauskova, \& Bezakova, 2014) define the environmental product as a product the impact of which on the environment, as well as the natural resources, is positive, taking the whole life cycle into consideration. Environmental product is quality product with long lifespan, made of non-toxic materials with the use of energetically effective production processes and supply, packaged in as little recyclable material as possible, not being tested on animals and not using endangered animal and plant species.

\section{Methodological approach, data and methods}

The presented study examines consumer behaviour with respect to the purchase of environmental products. The main aim of the paper is to present the outcomes of research, which focused on the investigation of the factors influencing product purchasing (including selected environmental factors), buying of environmental products, bio products and organic food in Slovakia. Following the main aim of the paper, we settled following partial aims:

to identify the various factors influencing consumer behaviour when purchasing products,

to examine the selected environmental factors influencing product purchasing (environmentally friendliness of products, ecological production, eco-labelling of products)

to find out which environmental products and how often the consumer purchase,

to investigate how consumers behave when purchasing bio products and organic food motives and barriers for the purchase of them, willingness to pay higher price for them).

In the order to meet the main aim of the paper, the secondary data analysis and quantitative empirical research have been carried out. In developing the literature review of the paper we applied a number of theoretical scientific methods (analysis, abstraction, historical-logical method, analogy, induction). We used a great variety of secondary data such as scholar book and journal literature, scientific papers, statistics and other reliable information and research works focused on detecting the issue of consumer behaviour and environmental responsible behaviour.

In the primary research we applied a quantitative descriptive consumer research in order to gain descriptive and characteristic data depicting consumer's purchase behaviour and influencing factors, including environmental aspects. Data were collected during the February 2017 via the most common tool of gathering data from a large number of respondents, i.e. the tool of questionnaire. Considering the form of questionnaire, the on-line one (processed via software Google Form) was chosen. A part of the respondents was approached personally (respondents of older age categories).

When constructing the questionnaire, we have taken into account the results of the secondary data analysis. The questionnaire had four parts - general section about factors influencing consumers' behaviour, the second section oriented on the aspects of environmental products buying and the third section focused on the purchasing bio products and organic food. The last part of the questionnaire served to find out socio-demographic information about the respondents. Various types of questions were utilized, mainly closedended questions (dual and multiple-choice response option) and scaling questions.

Gained data was firstly coded and processed by using spreadsheet software Excel and then analysed by statistical software SPSS (Statistical Package for Social Sciences) by applying various tests (binomial test, Chi-square test, Friedman test, Wilcoxon test, Cramer's $\mathrm{V}$ test) and finally processed by the tables form better imagination of obtained information. 
The subjects of our survey were consumers in Slovakia. After verification of questionnaires, 274 respondents (older than 18 years, both gender, different regions, different achieved levels of education, income) could be included to the survey sample. The structure of the sample of respondents by gender and age is shown in the following Table 1:

Table 1. Research sample - gender and age

\begin{tabular}{|c|c|c|c|c|c|}
\hline $\begin{array}{l}\text { Gender of } \\
\text { respondents }\end{array}$ & Frequency & $\begin{array}{l}\text { Percentage of } \\
\text { frequency }\end{array}$ & $\begin{array}{c}\text { Age of } \\
\text { respondents }\end{array}$ & Frequency & $\begin{array}{l}\text { Percentage of } \\
\text { frequency }\end{array}$ \\
\hline \multirow[b]{2}{*}{ Male } & \multirow[b]{2}{*}{130} & \multirow[b]{2}{*}{47.45} & $18-25$ years & 37 & 13.50 \\
\hline & & & $26-35$ years & 60 & 21.90 \\
\hline \multirow[b]{2}{*}{ Female } & \multirow[b]{2}{*}{144} & \multirow[b]{2}{*}{52.55} & $36-45$ years & 49 & 17.88 \\
\hline & & & $46-60$ years & 67 & 24.45 \\
\hline \multirow[b]{2}{*}{ Total } & \multirow[b]{2}{*}{274} & \multirow[b]{2}{*}{100.00} & 61 and more & 61 & 22.26 \\
\hline & & & Total & 274 & 100.00 \\
\hline
\end{tabular}

Source: own processing based on research results

Research sample follows the structure of population in Slovakia in the terms of gender and age. The representativeness of the sample according to the mentioned demographic features through the Chi-square test were verified (p-value gender 0.666; $p$-value age 0.802) on the level of significance $\alpha=0.05$ ) (Table 2):

Table 2. Results of Test on Representativeness of Research Sample

\begin{tabular}{|c|c|c|c|}
\hline Gender & Observed N & Expected N & Residual \\
\hline Man & 130 & 133.6 & -3.6 \\
\hline Woman & 144 & 140.4 & 3.6 \\
\hline Total & 274 & & \\
\hline \multicolumn{4}{|c|}{ Test Statistics } \\
\hline & & & Gender \\
\hline Chi-Square & & &, $187^{\mathrm{a}}$ \\
\hline $\mathrm{df}$ & & & 1 \\
\hline Asymp. Sig. & & & .666 \\
\hline \multirow[t]{3}{*}{ Monte Carlo Sig. } & Sig. & &, $674^{\mathrm{b}}$ \\
\hline & \multirow[t]{2}{*}{$99 \%$ Confidence Interval } & Lower Bound & .662 \\
\hline & & Upper Bound & .686 \\
\hline Age & Observed N & Expected N & Residual \\
\hline $18-25$ years & 37 & 34.5 & 2.5 \\
\hline $26-35$ years & 60 & 53.2 & 6.8 \\
\hline $36-45$ years & 49 & 52.7 & -3.7 \\
\hline $46-60$ year & 67 & 68.3 & -1.3 \\
\hline 61 and more & 61 & 65.3 & -4.3 \\
\hline Total & 274 & & \\
\hline \multicolumn{4}{|c|}{ Test Statistics } \\
\hline \multicolumn{4}{|r|}{ Age } \\
\hline Chi-Square & & & $1,635^{\mathrm{a}}$ \\
\hline $\mathrm{df}$ & & & 4 \\
\hline Asymp. Sig. & & & .802 \\
\hline \multirow[t]{3}{*}{ Monte Carlo Sig. } & Sig. & &, $810^{\mathrm{b}}$ \\
\hline & \multirow[t]{2}{*}{$99 \%$ Confidence Interval } & Lower Bound & .800 \\
\hline & & Upper Bound & .820 \\
\hline
\end{tabular}

Source: own processing based on research and SPSS results 
According to the highest achieved level of education, the largest part comprised of respondents with university education - master's degree $(48.18 \%)$, followed by respondents with high school education (41.24 \%) and bachelor's degree $(8.76 \%)$. The least represented were respondents with elementary education $(1.82 \%)$. We have also investigated the net monthly income of the respondents. The most numerous group comprised of respondents with a net income from 501 to 700 EUR $(29.93 \%)$. Followed by respondents with a net income from 701 to 1000 EUR (26.64 \%) and respondents with net income from 331 to 700 EUR monthly (16.42\%) According to the place of residence, respondents from Banská Bystrica region were dominant $(59.85 \%)$. Other regions were less represented. The representativeness of the sample was not achieved with the above-mentioned demographic characteristics.

\section{Conducting research and results}

In the first part of the survey we focused on factors influencing consumer behaviour. Respondents had to express the extent of agreement or disagreement with statements which were oriented on the impact of selected consumers' behaviour factors on their purchasing decisions. The aim was to determine the most important factors influencing consumers (among them were also environmental factors: environmentally friendly product, environmental performance of businesses, bio-product label). We found out that considered factors are not equally important to consumers. Quality of products was one of the most influencing factors (as much as $272-99 \%$ of respondents identify with it, 165 completely, men more than women). Safety (89\%) and price $(90,8 \%)$ of the products followed. Our findings correspond to the result of Flash Eurobarometer 367 (EC, 2013) - the quality of the product was the most important consideration for EU consumers (Slovak consumers $96 \%$, EU $2797 \%$ ) followed by the product's price (Slovakia $85 \%$, EU $2787 \%$ ) and its environmental impact (Slovakia $83 \%$, EU $2784 \%$ ). The least important factor to consumers (of the investigated in this research) was the brand name of the product (Slovakia $56 \%$, EU $2746 \%)$.

Regarding the environmental factors $-69 \%$ of respondents (completely only $20 \%$ ) preferred environmentally friendly products. Products made ecologically were chosen by $56.2 \%$ of questioned. Product label "bio" is very important and important for more than $40 \%$ of the respondents. Complete results are in the Table 3. We verified the statement about equal importance of all the factors while purchasing by Friedman test. With the significance level $\alpha$ $=0.05$ ( $\mathrm{p}$-value is .00) we accept the hypothesis that analysed factors are not equally important to the respondents while purchasing products. We found out mean values of particular factors with Friedman test and we arranged them from lowest to highest (Table 4). 
Table 3. Factors influencing consumer behaviour

\begin{tabular}{|c|c|c|c|c|c|}
\hline I choose product which ... & $\begin{array}{l}\text { Absolutely } \\
\text { agree }\end{array}$ & $\begin{array}{c}\text { More agree } \\
\text { than } \\
\text { disagree }\end{array}$ & $\begin{array}{c}\text { More } \\
\text { disagree } \\
\text { than agree }\end{array}$ & $\begin{array}{c}\text { Absolutely } \\
\text { disagree }\end{array}$ & No attitude \\
\hline ... is of good-quality. & 165 & 107 & 1 & 0 & 1 \\
\hline ... is safe. & 138 & 106 & 10 & 1 & 19 \\
\hline ... is affordable price. & 116 & 133 & 20 & 3 & 2 \\
\hline ... has quality service. & 86 & 134 & 33 & 3 & 18 \\
\hline ... is made in Slovakia. & 87 & 127 & 29 & 16 & 15 \\
\hline ...is with good image of producer. & 63 & 141 & 45 & 9 & 16 \\
\hline ...is environment-friendly. & 57 & 132 & 46 & 15 & 24 \\
\hline $\begin{array}{l}\ldots \text { is recommended to me by my } \\
\text { acquaintance. }\end{array}$ & 43 & 149 & 56 & 17 & 9 \\
\hline ... is labelled with a quality mark. & 47 & 116 & 71 & 20 & 20 \\
\hline ...is ecologically produced. & 40 & 114 & 66 & 25 & 29 \\
\hline $\begin{array}{l}\text {...has "bio product"/"organic food" } \\
\text { label. }\end{array}$ & 16 & 94 & 98 & 44 & 22 \\
\hline ... respects my religious values. & 45 & 53 & 51 & 88 & 37 \\
\hline ... has extended guarantee period. & 23 & 68 & 97 & 50 & 33 \\
\hline ... declares my social status. & 10 & 44 & 98 & 77 & 45 \\
\hline
\end{tabular}

Source: own processing based on research results

Table 4. Friedman test - Factors influencing consumer behaviour

\begin{tabular}{cc}
\hline & Mean Rank \\
\hline quality & 3.87 \\
\hline safety & 4.98 \\
\hline price & 5.06 \\
\hline quality service & 6.20 \\
\hline made in Slovakia & 6.52 \\
\hline image of producer & 6.95 \\
\hline environmental friendliness & $\mathbf{7 . 4 0}$ \\
\hline recommendations of acquaintance & 7.41 \\
\hline quality mark & 7.98 \\
\hline ecological production & $\mathbf{8 . 3 8}$ \\
\hline "bio" product label & $\mathbf{9 . 5 6}$ \\
\hline religious values & 9.70 \\
\hline extended guarantee period & 9.88 \\
\hline social status & 11.11 \\
\hline
\end{tabular}

Source: own processing based on research and SPSS results

Across European countries there is a variety in consumer purchasing behaviour of environmentally friendly products. According to Knoskova (2014) the EU citizens can be segmented into six categories regarding their environmentally friendly products purchasing (Regular maintenance, Occasional maintenance, Ready for action, Contemplation, Relapse, Reluctant). The maintenance behaviour stages (regular and occasional - consumer often/sometimes buys environmentally friendly products) are the most common in every EU Member State (with more than $60 \%$ of citizens at this stage in every country). Citizens are most likely to be at a maintenance behaviour stage in Austria (93\%), Germany (90\%) and 
Sweden $(89 \%)$. Austria is the only country where the relative majority of citizens are at the regular maintenance behaviour stage (48\%). This behaviour is also prevalent in Germany (37 $\%)$. The ready for action behaviour stage is most common in Bulgaria (11\%), Romania (8\%), the Czech Republic (7\%) and Slovakia (7\%). Green market in these countries has the highest potential to attract new customers (EC, 2013).

Subsequently we asked respondents about the purchasing of selected environmentally friendly products. They could mark their answers on 6-notch scale from "I buy regularly" to "I do not buy". We arranged particular products according to the frequency of their purchase by respondents. We determined a hypothesis that respondents buy all the environmentalfriendly products equally often. The statement about product purchasing equality was verified with Chi-Square test. We can reject this hypothesis (p-value .000) on a significance level of $\alpha$ $=0.05$. Mean values of products (Friedman test) were arranged from lowest to highest (Table 5).

Table 5. Friedman test - Environmentally friendly products

\begin{tabular}{cc}
\hline & Mean Rank \\
\hline Products of local farming & 3.46 \\
\hline Products packed in recyclable materials & 4.40 \\
\hline Meat and other products from eco-breeding & 4.82 \\
\hline Bio products & 4.86 \\
\hline Products from natural materials & 5.04 \\
\hline Energy-saving products & 5.21 \\
\hline Chemical-free products & 5.31 \\
\hline Organic food & 5.80 \\
\hline Products not tested on animals & 6.11 \\
\hline
\end{tabular}

Source: own processing based on research and SPSS results

We will determine the order of particular products by Wilcoxon's test of statistical significance. To determine the order of particular factors we compared the p-value with the significance level $\alpha=0.05$. If the $p$-value is lower than the significance level, we reject nullhypothesis about factor equality. Statistical significance proved only in two cases (Table 6).

Table 6. Wilcoxon's test - Environmentally friendly products

\begin{tabular}{crr}
\hline How often do you buy environmentally friendly products? Products... & From & $\begin{array}{c}\text { Asymp. Sig. (2- } \\
\text { tailed) }\end{array}$ \\
\hline packed in recyclable materials - local farming & $-4,303^{\mathrm{b}}$ &, $\mathbf{0 0 0}$ \\
\hline eco-breeding - packed in recyclable materials & $-1,955^{\mathrm{b}}$ &, $\mathbf{0 5 1}$ \\
\hline bio products - eco-breeding &,$- 722^{\mathrm{b}}$ &, 470 \\
\hline natural materials - bio products &,$- 211^{\mathrm{c}}$ &, $\mathbf{8 3 3}$ \\
\hline energy-saving - natural materials & $-1,862^{\mathrm{b}}$ &, 063 \\
\hline chemical-free - energy-saving &,$- 067^{\mathrm{b}}$ &, $\mathbf{9 4 6}$ \\
\hline organic food - chemical-free & $-3,052^{\mathrm{b}}$ &, $\mathbf{0 0 2}$ \\
\hline not tested on animals - organic food & $-1,398^{\mathrm{b}}$ &, $\mathbf{1 6 2}$ \\
\hline
\end{tabular}

Source: own processing based on research and SPSS results

Respondent of our research buys products of local farming most often. Regularly $27.4 \%$ of respondents buy them. They are predominantly young people (18-25 years). From 
this age group as much as $40.5 \%$ buy them regularly and $35.1 \%$ one to three times a month. Also the greatest part of respondents who buy products of local farming regularly were willing to pay higher price for bio products/organic food compared to conventional products.

Second most frequent purchased by respondents were six kinds of products, as they did not prove statistically significant. They were products packed in recyclable materials, products from ecological breeding, bio products, products from natural materials, energysaving and chemical-free products. Products packed in recyclable materials are regularly bought by $22.5 \%$ of our respondents. Again, young respondents predominated.

The results of our research about bio products purchasing were interesting. In our sample, $14.2 \%$ buy them regularly and one to three times a month $28.5 \%$ of questioned. According to the research of TNS Slovakia (May 2015), almost one third (29\%) of Slovak consumers buy bio products. From these $42 \%$ buy at least once a week and approximately quarter $(24 \%)$ exceptionally. Slovaks buy bio products, because they consider them healthy and of higher quality than classic products, and also because they are grown without chemicals.

Stated four kinds of products ( $\mathrm{a}-\mathrm{d}$ in Table 7), which are bought most often by our respondents, belong to products of everyday use. Majority of our respondents buy them regularly or several times a month, which we consider positive. It expresses their interest in the environment. With this purchase they also contribute to the protection of the environment or to lowering its excessive waste burden. The following product ( $\mathrm{e}-\mathrm{g}$ in Table 7 ) belong to products of medium-term and long-term consumption. Our respondents do not buy them that often - mostly one to five times a half-year.

Organic food and products not tested on animals $(\mathrm{g}-\mathrm{i})$ were in the third group of products according to the frequency of their purchase. More than a quarter $(25.2 \%)$ of the respondents do not buy organic food at all. At least once a year $56.9 \%$ of questioned buy them, more women than men. Also MB Brand Management agency monitored purchasing of organic food. In 2016 it conducted a research on a sample of 1460 respondents aged 18 to 69 years. The outcome was that $55 \%$ of Slovak consumers buy organic food, $11 \%$ stated that their partner buys them and a third of consumers do not buy them at all. Men (48\%) and women (52\%) buy organic food almost equally. Women tend to view the supply of organic food on the Internet and subsequently buy them in a store. Men do it the other way around, they view the supply in a store first and then buy it cheaper on the Internet. Overview of complete results about the frequency of environmental products purchasing are stated in Table 7.

Table 7. Environmental products purchasing frequency

\begin{tabular}{|c|c|c|c|c|c|c|}
\hline How often do you buy stated environmental products? & Regularly & $\begin{array}{c}\text { 1-3 times a } \\
\text { month }\end{array}$ & $\begin{array}{c}1-5 \text { a half- } \\
\text { year }\end{array}$ & $\begin{array}{c}\text { Once a } \\
\text { year }\end{array}$ & Less often & $\begin{array}{c}\text { I do not } \\
\text { buy }\end{array}$ \\
\hline a. Products of local farming (e.g. vegetables, cheese, milk...) & 75 & 93 & 54 & 8 & 30 & 14 \\
\hline . Products packed in recyclable materials (e.g. returnable bottles) & 62 & 67 & 63 & 14 & 38 & 29 \\
\hline c. Products of eco-breeding (meat...) & 38 & 73 & 67 & 27 & 29 & 40 \\
\hline d. Bio products & 39 & 78 & 47 & 22 & 52 & 36 \\
\hline e. Product from natural materials (e.g. clothing) & 24 & 55 & 95 & 41 & 42 & 17 \\
\hline $\begin{array}{l}\text { f. Energy-saving products (e.g. energy-saving light bulbs, } \\
\text { appliances) }\end{array}$ & 32 & 37 & 72 & 65 & 58 & 10 \\
\hline g. Chemical-free products (cosmetics, cleaning products) & 24 & 52 & 84 & 41 & 45 & 28 \\
\hline h. Organic food (yoghurts...) & 24 & 64 & 48 & 20 & 49 & 69 \\
\hline 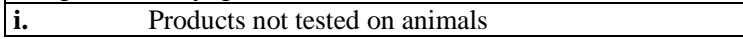 & 24 & 41 & 57 & 25 & 59 & 68 \\
\hline
\end{tabular}

Source: own processing based on research results 
Organic food and bio products are often perceived as environmentally friendly, healthy and tasting better than conventional food. The development of organic food and bio products market constitutes an element of a far more complex phenomenon of environmentally friendly consumption. We observe a dynamic growth in the value or organic food market in developed economies. From 2004 to 2012, the size of the European organic food market doubled, reaching 22.8 billion EUR. However, it was still a relatively small segment of the entire food and drink retail turnover (Bryła, 2012).

In our research we also analysed the motives for the purchase of bio products and organic food in more detail. Respondents could mark maximum three of the offered options (among which was also "I do not buy them" and "it does not concern me"). Overall, we collected 604 answers, respondent marked two answers on average. Respondents mostly inclined to the reason that they buy bio products and organic food because they are of good quality (as much as $21 \%$ of all answers, $45.4 \%$ respondents). Women and men answered approximately equally, consumers with higher incomes prefer this reason. As much as $60 \%$ of respondents from the segment "Greenback Greens" (consumers who are willing to pay more for environmentally friendly products) marked quality an important factor.

Number of respondents $(40.9 \%)$ inclined to the positive effect of bio products/organic food on health. Healthy lifestyle followed, which was stated as a reason by $30.3 \%$ of respondents. Also, the research of Nielsen Admosphere agency from October 2016 showed that Slovaks are relatively strongly interested in healthy lifestyle. According to this research one third of Slovaks try to consume the recommended daily intake of fruits and vegetables, one quarter take essential vitamins and minerals. Also, more than a quarter of Slovaks stated that they consider themselves healthy-eating (www.retailmagazin.sk).

On the fourth place was environmental friendliness of bio products/organic food (28.8\% of respondents), the aspiration to support environmentally conscious businesses $(24.5 \%)$ and the enjoyment from purchasing bio products/organic food (13.8\%).

Other reasons were not significant. The option "I do not buy" was marked mostly by respondents from segments which are not interested in the environmental protection. From the segment "Grousers" organic food and bio products are not bought by $60 \%$ of questioned and in the segment "Basic Brown" as much as $88.9 \%$ of respondents. From segment "Sprouts" they are not bought by approximately a third of the particular segment.

Magnusson et al. (2003) confirm that health concern is a better predictor of the purchase of organic food than concern for the environment. The overwhelming majority of studies find "health" to be the primary reason for consumers by organic food or bio product (f. e. Chinnici et al., 2002; Zanoli \& Naspetti, 2002). Healthy content came first in the mind of consumers over environmentally safe, satisfies changing taste, attitude of the customers according to the outcomes of the study of Paul and Jana (2012) too. According to survey by Bryła (2016) health values (50.6\%) and the ecological (environmentally friendly) character $(46.9 \%)$ play a key role in the process of organic food selection in Poland. Food safety and taste were mentioned by over $30 \%$ of the respondents (1000 inhabitants of Poland aged 1565 ) in top 5 motives. The fifth rank was taken by quality assurance in the form of a label of certificate.

We asked the respondents who stated that they do not buy bio products or organic food about their reasons. However, the question was also answered by respondents who only purchase one of the mentioned products or had an urge to express themselves to this question $-51.8 \%$ of respondents did so. Respondents could also choose maximum three possible answers - there were 274 answers overall. The most frequent reason for not buying bio products/organic food is their price - they seem too expensive (35\% of all answers). Another reason stated by $30 \%$ of our respondents was that they are not confident about the quality of 
bio products/organic food. Also, according to the agency research from 2015 (TNS Slovakia), the main reason for not buying bio products is the high price - as much as $61 \%$ of Slovaks answered so. One third of consumers (32\%) do not trust the bio label and one fifth $(20 \%)$ are not informed enough about bio products or they do not consider them quality enough (www.tns-global.sk).

The similar reasons are presented in more research studies focused on the purchase of environmental products in general. For example, Mala at al. (2018) stated that the most frequently indicated reason that discourages consumer from buying green products is their high price. Other reasons that are frequently marked by their respondents were insufficient information about products and their low availability in the market which was followed by "I am not sure about the quality of these products". The next finding, they presented is the consumers often believe that the information provided by enterprises about their "green" products and the impact of their activities on the environment are misleading, which is because of the fact that the enterprises primarily focus on improving their sales and image.

We surveyed the willingness of consumers to pay higher price when purchasing bio products/organic food in the next question. The majority of respondents stated that they are willing to pay more for bio products/organic food only when it is a certain kind of product $(22 \%)$ and only occasionally (21\%). Respondents who are willing to pay more (18\%), or more precisely, pay higher price increased by $10 \%$ maximum in comparison with competitive products $(16 \%)$, followed. Mostly respondents from the segment "Greenback Greens" were willing to pay higher price. In relation to the income, respondents with income higher than 1000 EUR per month $(29.3 \%)$ predominated.

The individuals' willingness to pay for the environment - which means to pay more for environmental friendly products - has been studied as a measure of propensity to act. Laroche et al. (2001) found that individuals who are likely to pay more for eco-friendly products are female, married, and with at least one child living at home. Witzke and Urfei (2001) applied a two-step procedure for estimating an indicator of regional willingness to pay, which could be useful for planning an efficient environmental policy in Germany.

According the Flash Eurobarometer 367 (EC, 2013) EU citizens are generally willing to pay somewhat more for products if they are confident that they are environmentallyfriendly $(77 \%)$. However, one in five citizens $(20 \%)$ is not willing to pay more for these products. The price premium that EU citizens are willing to pay for "green" products varies substantially. Four out of ten respondents say that they would be willing to pay $5 \%$ more for environmentally friendly products $(37 \%)$, three out of ten say that they would be willing to pay $6-10 \%$ more $(28 \%)$. Seven percent of respondents say that they would be willing to pay 11-20\% more, and just five percent of respondents would pay more than $20 \%$ extra for environmentally friendly products. Citizens are most willing to pay more for products that they are confident are environmentally friendly in Austria (88 \%), Sweden (87\%), Germany $(86 \%)$, Slovakia (86 \%) and the Czech Republic (86\%) and are least willing to pay more in Lithuania (64\%), Portugal (64\%) and Estonia (65\%).

In our research we assumed that there is a correlation between the income of respondents and their willingness to pay higher price for bio products/organic food. We verified this hypothesis with correlation characteristics for nominal variables. Pearson $\mathrm{p}$-value is 0.045 which is less than $\alpha=0.05$. We reject the null hypothesis (presumption about variable independence) on this significance level and we accept the presumption that respondents' income and their willingness to pay higher price for bio products or organic food are dependent. Cramer's V determines the strength of the dependence of the stated variables, its value is 0.170 which is only a weak dependence (Table 8 ). 
Table 8. Dependence of willingness to pay higher price and income

\begin{tabular}{|c|c|c|c|c|c|c|}
\hline \multicolumn{7}{|c|}{ Symmetric Measures } \\
\hline & & \multirow{2}{*}{\multicolumn{2}{|c|}{ Approx. }} & \multicolumn{3}{|c|}{ Monte Carlo Sig. } \\
\hline & & & & \multicolumn{3}{|c|}{$99 \%$ Confidence Interval } \\
\hline & & Value & Sig. & Sig. & Lower Bound & Upper Bound \\
\hline \multirow{3}{*}{ Nominal by Nominal } & Phi & .340 & .046 & $.042^{\mathrm{c}}$ & .037 & .047 \\
\hline & Cramer's V & .170 & .046 & $.042^{\mathrm{c}}$ & .037 & .047 \\
\hline & Contingency Coefficient & .322 & .046 & $.042^{\mathrm{c}}$ & .037 & .047 \\
\hline $\mathrm{N}$ of Valid Cases & & 274 & & & & \\
\hline
\end{tabular}

\section{Source: own processing based on research and SPSS results}

It can be summed up, there is variety of the motives for the purchase and non-purchase of bio products and organic food. Consumers in Slovakia buy organic food primarily due to its perceived health benefits and higher perceived quality of products (the regular consumers of the bio- and organic products). Little knowledge exists about the motivation/demotivation of the occasional organic food consumers (which is purchasing selected categories of organic food or only occasionally purchase organic products). The research outcomes shown the need for further research activities in this topic with the aim to better understand the behaviour of "green" and "organic" consumers.

If consumers cannot distinguish organic and bio from conventional food on reasonable criteria, it is not surprising that they do not purchase organics at greater rates. It is incumbent on marketers, retailers and producers to better convey relevant information to consumers. Appropriate educational materials that could broaden the organic food consumer base need to be developed. Marketers need to include not only information about positive health effects, better quality, taste, nutritional concern, but also information pertaining to production methods, environmental benefits, positive contribution to local economies, etc. (Hughner et al., 2007).

Surprising conclusion of our research was the classification of our respondents to predefined segments according to their attitudes towards the environmental protection and their environmental behaviour (Roper's Segmentation, In: Musova, 2013). Segments were briefly defined, with an emphasis on environmentally friendly product preference, and respondents had to place themselves into one of them based on their self-evaluation. Majority of the respondents placed themselves to the segment "Sprouts" $-44.2 \%$. They are respondents who contribute to the protection of the environment occasionally and sometimes buy environmental product. However, they can be influenced and are good target group for environmental marketing activities of businesses. 98 of respondents (35.8\%) placed themselves to the segment "Greenback Greens" which is typical by stronger willingness to pay higher prices for environmentally friendly products. Among the active protectors of the environments "True-Blue Greens" placed themselves $13.1 \%$ of questioned (36 respondents). Positive is that only 19 questioned (6.9\%) were indifferent in terms of the environmental protection. Based on the results of similar researches, we consider this finding debatable.

According to the results of preliminary questionnaire survey (Musova \& Musa, 2017) from March 2016 (420 respondents, Slovakia) most of respondents (42\%) occupied so-called selective approach (they manifest environmental responsibility in some activities or while purchasing). We could compare them with the segment Sprouts, frequency of this group is similar in both researches. However, significant differences were seen in other groups. Almost $26 \%$ reflected insufficient interest in solving environmental problems (in current research - Grousers - only 10 respondents $(3.4 \%)$. Whereas - only $9 \%$ of respondents from 
preliminary survey expressed an active approach to environmental issues (in current research True Blue Greens $13.1 \%$ of questioned. In the current research, also number of so-called "Greenback Greens" increased rapidly from $13 \%$ (in 2016) to current $35.8 \%$. We explain the stated disproportions as follows: in the research sample from 2017, people with higher education level and higher income predominated, which could have positively affected their environmental attitudes and behaviour (and subsequently the research results). The second reason could have been the fact that self-evaluation of the consumers was not completely honest, and consumers could have slightly adjusted the answers in favour of their environmental orientation, in effort to "whitewash" themselves.

The consumer's perception about his/her role in protecting the environment represents a personal aspect, since an individual could be more or less involved in protecting the environment regardless of his/her concern about the situation. The percentage of individuals declaring they could have an active role in protecting the environment is about 10 points lower than the percentage related to the general level importance given to the environment. As regards to territorial differences, the most ecologically-aware individuals are the citizens of the Netherlands (over 96 per cent declared that they can play a key role in protecting the environment), Sweden (93.34\%), Malta (93.69\% and Greece (92.91\%). On the contrary, Lithuania $(73.15 \%)$ and Latvia $(71.47 \%)$ are countries whose citizens are less concerned (Pirani \& Secondi, 2011).

\section{Conclusion}

Growing environmental problems caused by industrialization have increased the environmental concerns of customers, businesses, communities and governments. An increasing number of consumers tend to purchase and consume products that are presented in an environmentally friendly way.

Based on primary data analysis from the questionnaire survey, we have identified the most important factors which influence consumers in Slovakia and their purchase decisionmaking. The results have shown that environmental factors are not as important for consumers, despite the negative development in the environment. Only $20.8 \%$ of the respondents have stated with certainty that they choose environmentally friendly products.

While purchasing selected environmentally friendly products, consumers in Slovakia regularly and rather often purchase mostly products of everyday consumption (from local farming, products packaged in recyclable packaging, products of eco-breeding and bio products. Our respondents purchase products of mid- and long-term consumption less often (mostly once to five times every half a year) - products from natural materials, energy-saving products and chemical-free products.

The results connected to the purchase of bio products and organic food were surprising. In some aspects they have met the results of presented agency surveys, in some not. In our research sample bio products are regularly purchased by $14.2 \%$ of the respondents and once to three times a month by $28.5 \%$ respondents. Organic food is purchased regularly by $8.7 \%$ respondents and once to three times a month by $23.3 \%$. The provided motives for the purchase were mostly the quality of the products (46.4\% of respondents), positive influence on health and their purchasing as a part of a healthy life style. The connection between purchasing bio products/organic food and environmental protection has been detected on the fourth place (more than $28 \%$ of respondents). More than $13 \%$ respondents do not purchase bio products at all, organic food is not purchased by a quarter of the respondents. The most common reasons for this is mainly higher price or the consumers 'disbelief in the quality of these products. 
Based on self-evaluation of attitudes towards environmental protection and purchasing environmental products, consumers could include themselves in predefined consumer segments. The majority of the consumers placed themselves as "Sprouts" - they act selectively - they contribute to the environmental protection occasionally and sometimes buy environmental product. More positive results (compared to the expected ones) have been achieved in consumer segments which are not concerned with environmental issues - only $9 \%$ of respondents perceived themselves as "Grousers" and "Basic Browns". We realize that more positive findings can be the result of research sample structure - consumers with higher education level and higher income predominated. Therefore, we consider several of our findings as debatable and they are an impulse for a further, more detailed research of this issue with an emphasis on relevant suggestions for consumers as well as for business practice.

\section{Acknowledgement}

This paper has been supported by the Scientific Grand Agency of Slovak Republic under project VEGA No. 1/0802/16 "The influence of innovative marketing concepts on the behaviour of chosen market subjects in Slovakia".

\section{References}

Barbarossa, C., \& Pastore, A. (2015). Why environmentally conscious consumers do not purchase green products A cognitive mapping approach. Qualitative Market Research, 18(2), 188-209. doi: 10.1108/QMR-06-2012-0030.

Bryła, P. (2015). The development of organic food market as an element of sustainable development concept implementation. Problemy Ekorozwoju, 10, 79-88.

Bryła, P. (2016). Organic food consumption in Poland: motives and barriers. Appetite, 105, 737-746.

Bui, M. H. (2005). Environmental marketing: A model of consumer behaviour. Proceedings of the Annual Meeting of the Association of Collegiate Marketing Educators. New Orleans: Loyola University, 20-28.

Chinnici G., D'Amico M, \& Pecorino, B. 2002. A multivariate statistical analysis on the consumers of organic products. British Food Journal 104 (3/4/5). 187-199.

Chiou, T., Chan, H., Lettice, F., \& Chung, S. (2011). The influence of greening the suppliers and green innovation on environmental performance and competitive advantage in Taiwan. Transportation Research Part E, 47(6), 822-836.

Diamantopoulos, A., Schlegelmilch, B. B., Sinkovics, R. R., \& Bohlen, G. M. (2003). Can socio-demographic still play role in profiling green consumers? A review of the evidence and an empirical investigation. Journal of Business Research, 56, 465-480. doi: 10.1016/S0148-2963(01)00241-7.

Esmaeilpour, M., \& Bahmiary, E. (2017). Investigating the impact of environmental attitude on the decision to purchase a green product with the mediating role of environmental concern and care for green products. Management \& Marketing. Challenges for the Knowledge Society, 12(2), 297-315. doi: 10.1515/mmcks-2017-0018.

European Commission. 2013. Flash Eurobarometer 367. Attitudes of Europeans Towards Building Single Market For Green Products. http://ec.europa.eu/public_opinion/ flash/fl_367_en.pdf

Finisterra do Paco, A., Barata Raposo, M., \& Filho, W. (2009). Identifying the green consumer: a segmentation study. Journal of Targeting, Measurement \& Analysis for Marketing, 17(1), 17-25. 
Fraj, E. \& Martinez, E. (2007). Ecological consumer behaviour: an empirical analysis. International Journal of Consumer Studies, 31(1), 26-33.

Gilg, A., Barr, S., \& Ford, N. (2005). Green consumption or sustainable lifestyles? Identifying the sustainable consumer. Futures, 37(6), 481-504.

Hughner, R. S., McDonagh, P., Prothero, A., Shultz II, C. J., \& Stanton, J. 2007. Who are organic food consumers? A compilation and review of why people purchase organic food. Journal of Consumer Behaviour. (6), 94-110. doi: 10.1002/cb.210.

Juwaheer, T., Pudaruth, S., \& Noyaux, M. (2012). Analysis the impact of green marketing strategies on consumer purchasing patterns in Mauritius. World Journal of Entrepreneurship, Management and Sustainable Development, 8(1), 36-59.

Kljucnikov A., Belas, J., Kozubikova, L., \& Pasekova P. (2016). The Entrepreneurial Perception of SME Business Environment Quality in the Czech Republic. Journal of Competitiveness, 8(1), 66-78.

Knoskova, L. (2014). Consumer Attitudes to Sustainability and Eco-Innovations. International Journal of Economic Practices and Theories, 4(3), 374-382.

Kotler, P., \& Armstrong, G. (2004). Marketing. Praha: Grada Publishing.

Krizanova, A., Majerova, J., \& Zvarikova, K. (2013). Green marketing as a tool of achieving competitive advantage in automotive transport. Transport means 2013. Kaunas: Kaunas University. 45-48.

Kumar, P., \& Ghodeswar, B. (2015). Factors affecting consumers'green product purchase decisions. Marketing Intelligence \& Planning, 33(3), 330-347.

Kurajdova, K., Taborecka-Petrovicova, J., \& Kascakova, A. (2015). Factors Influencing Milk Consumption and Purchase Behavior - Evidence from Slovakia. Procedia Economics and Finance, 34, 573-580.

Kusa, A. (2012). Atribúty environmentálneho marketingu a ich vplyv na spotrebitel'ov. Podnikanie v konkurenčnom prostredí. Komárno: Univerzita J. Selyeho, Ekonomicka fakulta.

Laroche, M., Bergeron, J., \& Barbaro-Forleo, G. (2001). Targeting consumers who are willing to pay more for environmentally friendly products. Journal of Consumer Marketing, 18(6), 503-520.

Magnusson M. K., Arvola, A., Hursti, U., Aberg, I., \& Sjoden, P. 2003. Choice of organic food is related to perceived consequences for human health and to environmentally friendly behaviour. Appetite, 40 (2), 109-117.

Mainieri, T., Barnett, E. G., Valdero, T. R., Unipan, J. B., \& Oskamp, S. (2010). Green Buying: The Influence of Environmental Concern on Consumer Behavior. The Journal of Social Psychology, 137(2), 189-204.

Mala, D., Sedliacikova, M., \& Bencikova, D. (2018). How Customers of Small and Medium Wood-processing Slovak Enterprises Perceive a Green Product. BioResources, 13(1), 1930-1950.

Marques, P. C., \& Almeida, D. (2013). A Path Model of Attitudinal Antecedents of Green Purchase Behaviour. Economics \& Sociology, 6(2), 135-144. Doi: 10.14254/2071789X.2013/6-2/12.

Mostafa, M. M. (2007). Gender differences in Egyptian consumers' green purchase behaviour: the effects of environmental knowledge, concern and attitude. International Journal of Consumer Studies, 31(3), 220-229.

Musova, Z. (2013). Spolocenska zodpovednost v marketingovej praxi podnikov. Banska Bystrica: Univerzita Mateja Bela, Ekonomicka fakulta. 
Musova, Z., Musa, H. (2017). Environmental responsibility in marketing activities of companies. Innovation Management, Entrepreneurship and Sustainability (IMES 2017). Prague: University of Economics, Faculty of Business Administration. 654-663.

Newton, J., Tsarenko, Y., Ferraro, C., \& Sands, S. (2015). Environmental concern and environmental purchase intentions: The mediating role of learning strategy. Journal of Business Research, 68(9), 1974-1981.

Ottman, J. A., Stafford, E., R. \& Hartman, C. L. (2006). Avoiding Green Marketing Myopia: Ways to Improve Consumer Appeal for Environmentally Preferable Products. Environment, 48(June), 22-36.

Paul, J. \& Rana, J. (2012). Consumer behaviour and purchase intention for organic food. Journal of Consumer Marketing, 29(6), 412-422. doi: 10.1108/07363761211259223

Pedrini, M., \& Ferri, M. L. (2014). Socio-demographical antecedents of responsible consumerism propensity. International Journal of Consumer Studies, 38(2), 127-138.

Pirani, E., \& Secondi, L. (2011). Eco-Friendly Attitudes: What European Citizens Say and What They Do. International Journal of Environmental Research, 5(1), 67-84.

Raletic Jotanovic, S., Sudarevic, T., Katic, A., Kalinic, M. \& Kalinic, C. (2016). Environmentally Responsible Purchasing - Analysis of the Ex-Yugoslavian Republics. Applied Ecology and Environmental Research, 14(3), 559-572. doi: http://dx.doi.org/10.15666/aeer/1403-559572.

Richterova, K., Klepochova, D., Kopanicova, J., \& Zak, S. (2015). Spotrebitel'ské správanie. Bratislava: Sprint 2.

Schiffman, L. G., \& Kanuk, L. L. (2004). Nákupní chování. Brno: Computer Press.

Shamsi, M. S., \& Siddiqui, Z. S. (2017). Green Product and Consumer Behavior: An Analytical Study: Petranika Journal of Social Science and Humanities, 25(4), 15451554.

Stead, J., \& Stead, E. (1996). Management for a Small Planet. $2^{\text {nd }}$ Edition. London: Sage Publication.

Witzke, P. H., \& Urfei, G. (2001). Willingness to Pay for Environmental Protection in Germany: Coping with the Regional Dimension. Regional Studies, 35, 207-214.

Zanoli R., \& Naspetti S. (2002). Consumer Motivations in the purchase of Organic Food. British Food Journal, 104 (8), 643-653.

Zauskova, A., \& Bezakova, Z. (2014). Green Innovations and their Implementation in the Slovak SMEs. Marketing Identity: Explosion of Innovations. Trnava: Faculty of Mass Media Communication, 442-454. 